\title{
THEORETICAL SUBSTANTIATION OF THE COMPETITIVENESS OF ACADEMIC STAFF FROM THE PERSPECTIVE OF EDUCATIONAL SCIENCES
}

\author{
*Marina Troskova, Irena Katane \\ Latvia University of Life Sciences and Technologies, Latvia \\ *Corresponding author's email: marina.troshkova@gmail.com
}

\begin{abstract}
The socio-economic changes brought about by globalisation, the internationalisation and digitalisation of higher education, as well as the current demographic situation in Europe and Latvia, raise the issue of the competitiveness of academic staff in the context of multicultural higher education. The aim of the study is to provide a theoretical basis for the competitiveness of academic staff in the view of educational sciences, respecting the different trends and based on the conceptual approaches in personal/specialist competitiveness research. The following research methods were used: study, analysis and evaluation of scientific literature (theoretical research method); reflection of personal experience (empirical research method). As a result of the theoretical research, two trends for the substantiation of the concept of competitiveness in the educational sciences were identified. The first trend: the competitiveness of a person is substantiated through transfers from economic and management science, with a particular emphasis on specialist marketability and employability as a significant manifestation of competitiveness. The second trend: according to the new paradigm of competitiveness in educational sciences, the competitiveness of a human as a person and as a specialist is based on the perspective of pedagogy and psychology. The research results led to the conclusion that there are three conceptual approaches in the methodology of competitiveness research: 1) qualitative approach: identifies and lists competitive personality traits and qualities; 2) functional approach: describes the competitive behaviour of a person or specialist; 3) structural approach: competitiveness is substantiated as a complex combination of personal/ specialist qualities, identifying several structural components. All of these approaches are also characteristic to the research of competitiveness of academic staff. The following taxonomy should be respected in the substantiation of academic staff competitiveness: 1) substantiation of personal competitiveness; 2) substantiation of specialist competitiveness in the context of different industries; 3) the substantiation of the competitiveness of specifically academic staff in the context of the specifics of higher education.
\end{abstract}

Key words: academic staff, competitiveness, employment, globalisation, marketability, sustainability of higher education.

\section{Introduction}

Nowadays, the process of globalisation is causing socio-economic changes, as well as internationalisation and digitalisation of the higher education environment, creating new challenges for students and academic staff alike. The process of globalisation raises the issue of competitiveness of every country, each particular society and each individual, including academic staff and students, as emerging professionals at local, national and global levels. There is a need for continuous self-improvement, both as a person and as a specialist, by interacting with the ever-changing socio-economic environment as a specialist.

Experience has shown that the current demographic situation in Latvia, including the declining number of graduates and students in higher education, poses a threat to the competitiveness and sustainability of higher education institutions. Therefore, academic staff must change their thinking, must develop themselves professionally, thus ensuring their competitiveness, including the capacity for work and professional self-actualisation in these ever-changing conditions. Personal experience of the authors shows that the modern higher education environment is beginning to lose its international borders: 1) international study programmes are being developed as a result of inter-university cooperation; 2) exchange of students and academic staff takes place within the framework of ERASMUS and other international cooperation agreements; 3) as the Latvian higher education environment becomes increasingly more open to international studies, more and more students from different countries are choosing programmes offered by Latvian higher education institutions; 4) the possibilities of distance education/e-studies in Latvian higher education are constantly expanding, which also attracts foreign students; 5) many foreign students wish to study in Latvia, while also getting acquainted with Latvian culture, including the language; at the same time, they need to communicate with the teaching staff in foreign languages which they are familiar with, so it is important to respect the culture and different needs of the foreign students studying in Latvia; 6) foreign academic staff increasingly more often wish to work in Latvian higher education institutions; 7) millennials begin their studies in Latvian higher education institutions. This sets new requirements for higher education. All these factors significantly raise the issue of competitiveness of the teaching staff in the multicultural environment of higher education.

There is another important factor that determines the topicality of academic staff competitiveness. That is, one of the goals of higher education is to promote the development of a competitive knowledge society, 
ensuring the development of the competitiveness of young specialists, where the readiness for independent, creative and responsible professional activity is one of the indicators of competitiveness (Katane \& İriste, 2013; Сохач \& Плугина, 2015).

In order to facilitate the development of teaching staff competitiveness, it must be possible to assess it. In order to develop the academic staff assessment methodology, it is necessary to develop the theoretical and methodological basis for academic staff competitiveness research from the point of view of educational sciences. It is necessary to identify the characteristics of academic staff competitiveness, its various manifestations in academic, research and organisational activities, thus developing a framework of indicators for assessing teaching staff competitiveness.

The topicality of the research on the competitiveness of educators, including academic staff, in the $21^{\text {st }}$ century educational environment, is evidenced by several scientific publications (Baranova, 2012; Bogoyavlenskaya \& Kliueva, 2013; Grebennikova \& Rybkin, 2017; Katane, 2011; Донина \& Стырова, 2018; Плугина, 2016; Скляр, 2018; Сохач \& Плугина, 2015; Харченко, 2014; Чупрова, 2004).

The aim of the study is to provide a theoretical basis for the competitiveness of academic staff in the view of educational sciences, respecting the different trends and based on the conceptual approaches in personal/specialist competitiveness research.

\section{Materials and Methods}

This study used the following theoretical research methods: study, analysis and evaluation of scientific literature, as well as an empirical research method: reflection of personal experience. The research was conducted in Latvia from 2019 to 2020.

The basis for the substantiation of academic staff competitiveness was the new competitiveness paradigm in educational sciences (Katane, 2010; Katane \& Kalniņa, 2010).

As a result of the theoretical research, two trends for the substantiation of the concept of competitiveness in educational sciences were identified (Katane, 2011; Katane \& Kalnina, 2010).

- The first trend: the substantiation of personal competitiveness is formed by using transfers from economic and management sciences, and by comparing the professionalism and competency of a specialist to a commodity in labour market conditions, highlighting these sets of qualities as the advantages of competitiveness (Cummins, 2012; Grebennikova \& Rybkin, 2017; İriste, 2018; Katane, 2011; Katane \& İriste, 2013; Lowden et al., 2011; Parker, 2008; Rothwell \& Arnold,
2007; Swanepoel et al., 2003; Sarfraz et al., 2018; Teichler, 2007; Unger et al., 2010; Митина, 2003; Широбоков, 2000).

- The second trend: the substantiation of personal competitiveness is based on a humancentric approach and humanist ideas and values in educational sciences and psychology (Grebennikova \& Rybkin, 2017; Iriste, 2018; Katane, 2011; Katane \& Īriste, 2013; Katane, Baltusite, \& Katans, 2017; Katans, 2019; Андреев, 2004; Андреев, 2013; Митина, 2003; Суязова et al., 2013; Холодцева, 2006; Шаповалов, 2006).

In educational sciences and psychology (in the methodology of these sciences) there are three conceptual approaches to researching human competitiveness (Īriste, 2018; Katane, 2010; Katane, 2011; Katane \& Kalniņa, 2010): 1) qualitative approach: identifies and lists competitive personality traits and qualities; 2) functional approach: describes the competitive behaviour of the person or specialist; 3) structural approach: competitiveness is substantiated as a complex holistic combination of personal/specialist qualities, identifying several structural components.

The following theoretical research developments can be observed in the substantiation of academic staff competitiveness: 1) substantiation of personal competitiveness; 2) substantiation of specialist competitiveness, identifying the common characteristics of competitiveness and ways of manifestation in the context of different industries; 3 ) the substantiation of academic staff competitiveness, focusing on the specifics of professional activities and the higher education environment.

\section{Results and Discussion}

Transfers from Economic and Management Sciences to Educational Sciences in the Substantiation of Competitiveness of Specialists as Professionals

Competitiveness is one of the interests to scientists from different disciplines. Social sciences assess the competitiveness of the state and/or company. From the point of view of economic and management sciences, competitiveness is defined as the ability of a company, sector or country to sell and provide goods and services in the labour market, which arises from the needs of a globally integrated labour market and benefits from international sales (European Commission, 2019). According to experts, the level of competitiveness depends on a number of factors, including labour costs, regulatory burden, productivity, skills, innovation, infrastructure and other factors. The competitiveness of a specialist is often compared to that of a company, as specialists, including academic staff, offer and sell their skills, 
knowledge and competences on the labour market (Cummins, 2012).

In several scientific publications, competitiveness is often replaced by the terms marketability and employability (İriste, 2018; Katane, 2011b; Katane \& İriste, 2013; Katane, Baltusite, \& Katans, 2017), as both marketability and employment are significant competitiveness indicators and manifestations. In the modern dynamic environment, which no longer offers long-term employment, the main goal of a specialist is to maintain and improve their attractiveness in the labour market (Parker, 2008). This, in turn, ensures the marketability of the specialist as a professional. Marketability of the educator/pedagogue, including academic staff, in the education environment, is determined by several factors: professionalism of the pedagogue, including competence; human qualities, including charisma; flexibility in thinking, actions and interactions with other people, including students and colleagues; ability to reconcile personal development goals with the development and sustainability goals of the educational environment in which they work (balance between ego-centred and eco-centred thinking and actions); the satisfaction of 'clients' of education - learners with the 'services' provided by the pedagogue, etc. (Katane, 2011b).

Russian scientists have also written about marketability as one of the manifestations of pedagogue competitiveness (Митина, 2003; Широбоков, 2000). For example, L. Mitina (Митина, 2003) emphasises the idea that a modern pedagogue is a competitive person if they are a marketable specialist in the labour market, who is capable of self-actualisation in their profession in a changing social, professional environment/work environment. S. Shirobokov (Широбоков, 2000) has also, when studying the competitiveness of teaching students as future teachers, emphasised the idea that teacher's competitiveness is primarily related to marketability in the labour market and marketability in society. How quickly and easily the goods can be sold depends on marketability. The same can be attributed to the marketability of a specialist, i.e. whether they are able to ensure their employment and how quickly they can find a new job if necessary (Parker, 2008). Thus, the concept of marketability is closely linked to the concept of employability.

The marketability of a specialist as an indicator of their competitiveness can be analysed and evaluated from two aspects: 1 ) internal aspect: the marketability arising from the specialist as a person, a professional in their field, which is determined by a set of specialist qualities that are highly valued in the professional field, including their various competences and competitive professional activities, which are both qualitative and productive, with expressions of creativity and innovation; 2) external aspect: the marketability resulting from the labour market environment, which is determined by the real situation in the labour market, i.e. if there are open vacancies in the labour market, then every professional has environmentally determined marketability; however, due to changes of the external environment, i.e., in the case of a reduction in the amount of jobs, the marketability of a specialist in a particular profession is reduced, and therefore also their competitiveness in terms of their employability opportunities (Katane \& İriste, 2013). These findings can also be attributed to the marketability of academic staff as a manifestation of competitiveness.

Employability (just like marketability) can be substantiated and interpreted as a single structure, consisting of two parts: internal and external. The internal part contains knowledge, skills and competences, which an individual possesses. On the other hand, the external part depends on the environment, i.e. the labour market. Employability is seen as the ability to ensure one's employability (Grebennikova \& Rybkin, 2017). It is important to emphasise here that employability includes several abilities: 1) ability to find their first job after graduating; 2) ability to retain the job; 3) ability to move from one job to another within the same organisation, taking on new duties, 4) ability to get a job in another organisation, if it is necessary, ensuring their career growth. Simultaneously, employability is not only the ability of professionals to find work in the labour market in circumstances of low demand for specific specialists, but also whether the pay at the new job is lower than what the specialist wants or whether it is below the industry average. If so, the newfound job is considered undesirable or unsustainable for their professional development. In other words, employability is the ability to find and retain a fulfilling job matching their competences and professional expertise, which is adequately valued and paid for by the employer.

From the aforementioned, the authors conclude that employability is also the ability to freely and flexibly move and adapt in the labour market, ensuring their mobility and career development, which is an important competitiveness indicator.

Scientist U. Teichler (2007) also suggests talking about increasing professional relevance of studies instead of graduate employability, where not only is the entry of graduates into the labour market important, but also the acquisition of such competences, skills and abilities which will ensure their professional mobility and long-term employability. The very definition of employability in the study of the Austrian scientist (Unger et al., 2010) triggered discussions and was ambiguous. The study concluded that higher education must not be directed towards short-term labour market demands. Higher education institutions must provide 
interdisciplinary skills, which are often referred to as key competences, and it is the acquisition of these skills that will ensure long-term employability, as professional skills become outdated too quickly.

Several publications (Rothwell \& Arnold, 2007) have shown that scientists are interested in both the marketability and employability of graduate students, including young pedagogues, in the labour market after obtaining their higher education and professional qualifications. For example, K. Lowden et al (Lowden et al., 2011) believe that employers should work together with higher education institutions to increase graduate marketability in the labour market. This is possible if employability skills are integrated into higher education programmes as the desired learning outcome. The study shows that employers value teamwork as well as the ability to solve problems. Recently the employability of graduates is viewed as a complex set of interrelated knowledge, skills and competences, which help individuals to become both safely and well-employed. There is also the opinion that employers particularly value general skills, analytical abilities and abilities that promote flexibility and adaptability. Employers highly value graduates being able to adapt to the organisational culture of the workplace, using their abilities and skills to develop in the organisation and to work with the new team. Graduates and specialists in general are expected to be proactive, be able to use advanced skills, including analysis and critical thinking.

Scientists (Safraz et al., 2018), in their substantiation of employability, describe various employability skills, particularly highlighting those qualities, skills and abilities of a competitive specialist that are most valued by employers and which can be considered competitive advantages. For example, the ability to work in a team; ability to solve problems; communication; computer skills; analytical thinking; leadership; time management; interaction and organisational skills; interaction, including cooperation, skills; the ability to solve problems is valued highest. Specialists need these qualities, skills and abilities for work in all industries and at all levels of the organisational hierarchy.

Therefore, for students and graduates to be competitive as specialists, professionals of their industries, including being in-demand and employed in the labour market, academic staff must also be competitive, including being in-demand and very competent in their academic activities and professional specialisation.

Substantiation of Competitiveness of a Human as a Person and as a Specialist in Their Professional Field in the View of Pedagogy and Psychology

At the turn of the $20^{\text {th }}$ and $21^{\text {st }}$ century educational sciences shifted from the old competitiveness paradigm to the new paradigm (Katane, 2010). According to the new paradigm, a competitive individual competes with themselves in their self-development: with their own weaknesses, inability and unwillingness. They are able to cooperate with others, viewing competitors as potential partners for cooperation. According to the new paradigm, a competitive person is creative, flexible, capable of making decisions, able to take responsibility for their decisions and consequences of their actions, able to solve non-standard situations and problems, capable of self-development and selfactualisation in a constantly changing environment. Such people view changes as new opportunities rather than threats, because they are able to take reasonable risks, master new things by taking on various challenges which arise during processes of change, are capable of changing themselves and changing their environment with their own innovations. Such specialists are respected by others and are in demand in the labour market.

The Russian academic V. Andreyev (Андреев, 2013), the founder of 'competitionology' (interdisciplinary educational science on human competitiveness), emphasises several ideal qualities of a competitive person: motives and orientation of values; moral, civil, intellectual and business values; character traits, communication and organisational skills, all of which influence the activities and behaviour of the person. V. Shapovalov (Шаповалов, 2005) also relies heavily on the qualitative approach when describing personal competitiveness. He emphasises that competitiveness is a sociallyorientated personality system, which includes abilities, character traits and other qualities, for example, self-confidence based on their own abilities and possibilities (Холодцева, 2006).

The substantiation of academic staff competitiveness also highlights a number of qualities that are characteristic of competitiveness: flexibility, mobility, adaptability, psychological readiness to receive and apply new information, learn new technologies, high levels of independence and accountability, high stress tolerance, need for success in professional activities, personal qualities of a humane person, various abilities and competences (Плугина, 2016; Чупрова, 2004).

The functional approach in competitiveness research is characteristic to those scientists who try to research and describe human competitive behaviour. For example, a competitive specialist is a specialist, whose work is equally high quality and productive regardless of whether they are being watched by someone from the management team. This demonstrates a high level of professionalism, which is an essential component of competitiveness (Katans, 2019). It is very important to note that a 
competitive specialist is someone who can (Katane, Baltusite, \& Katans, 2017; Katans, 2019): 1) selfactualise in a constantly changing environment; 2) not only achieve success, but also be able to overcome failures in the process of development, finding new strength within themselves for new development. These findings are largely based on the synergistic approach in psychology and educational sciences, as human development is a multi-cyclical and non-linear process. One of the most important characteristics of competitive behaviour is the need of a person for self-actualisation (Митина, 2003), which A. Maslow wrote about (Maslow, 1968) when researching selfsufficient personalities. This need becomes a powerful motivator for professional self-development. R. Miller and V. Frankl (cited in Холодцева, 2006) also believed that competitive behaviour is based on a developed need for success. Human health is an important indicator of competitiveness, as it is an important factor that significantly influences the process of selfactualisation. The significant features of academic staff competitive behaviour are: 1) Continuous reflection on one's pedagogical activity and professionalism, readiness and ability to constantly seek education and self-educate throughout their entire professional life (Чупрова, 2004); 2) competently organising the study process, facilitating the formation and development of each student's personality as a future specialist, aiding the development of their moral and intellectual selfdevelopment motivation management system (Coxaч \& Плугина, 2015); 3) active teaching staff position and readiness to improve one's skills in working with scientific, methodological and teaching frameworks; professional and personal self-development, readiness to learn innovative methods; incorporating creativity in work with students; a holistic and systemic approach to ensuring a scientific and methodological basis; development of a scientific methodological orientation; methodological competence of the teaching staff and involvement in the development of the scientific and methodological framework for studies (Харченко, 2014). In her doctoral thesis S. Baranova (Baranova, 2012) emphasises that competitive academic staff is aware of its resources, potential for development and professional development, self-searching and selfevaluation become the basis for further education.

The structural approach is characteristic to those researchers, who substantiate and describe competitiveness as a complex multicomponent structure (İriste, 2018; Kalnina, 2010; Katane, 2010; Katane, 2011; Katane \& Kalnina, 2010; Митина, 2003; Шаповалов, 2005) or multilevel hierarchical structure (Grebennikova \& Rybkin, 2017; Katans, 2019), creating competitiveness structure models. For example, L. Mitina (Митина, 2003) highlights the following components in the competitiveness structure: personality direction, competence and flexibility. Other researchers also emphasise that competence is an important component of a specialist's competitiveness structure (İriste, 2018; Katane, 2011; Katans, 2019), which simultaneously is also significant capital of a human (Bogoyavlenskaya \& Kliueva, 2013). It is important to facilitate the development of each specialist's competence, including professional competence and its level, as this will also have a significant impact on the development of competitiveness in general. In the model developed by V. Grebennikova and A. Rybkin (Grebennikova \& Rybkin, 2017), competitiveness consists of three basic levels: 1) general level - competitiveness as a scientific category in a broad sense, which includes the competitiveness of the society, economy, organisation and humans; 2) special or specific level: the object or subject of competitiveness is specified by focusing on the specific subject of the research, for example, competitiveness of a company or person; 3) individual or personal level: the competitiveness of a specialist of a specific industry, for example, the competitiveness of a pedagogue, which is affected by all the previously mentioned competitiveness levels, and vice-versa - the competitiveness of the pedagogue ensures the competitiveness of the educational institution, in which they work, as well as of the entire society in the specific socioeconomic circumstances. The educator's level of competitiveness describes the ability to handle and accept challenges. Based on the structural approach, the author (Katane, 2011) of the article has developed the structural model of an educator's competitiveness, identifying five components of competitiveness: 1) component of personality direction, including professional direction; 2) component of self-conception; 3) component of self-regulation and self-management, including volition, emotional intelligence and personality's flexibility; 4) component of competences, including professional competences; 5) component of individual qualities (for example, intelligence, charisma, sense of humour, creativity, different characteristic features, health, etc.), and the basis for the development of an educator's competitiveness is experience.

It can therefore be concluded that research of academic staff competitiveness already has a significant theoretical and methodological basis, and all three conceptual approaches are being used. At the same time, it is important to focus on the specifics substantiating academic staff competitiveness, as the specifics of academic, research and organisational activities, as well the specifics of the higher education environment allow one to distinguish the unique aspects through which the description of teaching staff competitiveness can differ from the general description of competitiveness of any person, industry 
or industry specialist. This outlines the prospects for future research.

\section{Conclusions}

1. The socio-economic changes brought about by globalisation, the internationalisation and digitalisation of higher education, as well as the current demographic situation in Europe and Latvia, raise the issue of the competitiveness of academic staff in the context of multicultural higher education.

2. The substantiation of academic staff competitiveness can be based on the interdisciplinary approach, using transfers from economic and management sciences. The marketability and employability of specialists in the labour market should be considered significant indicators and manifestations of competitiveness.

3. In pedagogy and psychology, the research of human competitiveness takes place under the influence of the new paradigm. There are three conceptual approaches (qualitative, functional and structural approach) to the competitiveness research of a person and specialist, including pedagogue/academic staff as a professional. In the context of competence and self-management, the substantiation of teaching staff competitiveness highlights the need for continuous selfdevelopment and professional development, ensuring self-actualisation. The method for selfdevelopment and self-actualisation is lifelong and lifewide education.

4. It is important to not only rely on the available general and common approaches to the research of competitiveness of various industry specialists, but to also focus on the unique manifestations of competitiveness and competitive behaviour of academic staff, because academic, research and organisational activities bring their own specificity to the research of academic staff competitiveness. Therefore, the following taxonomy should be respected in the substantiation of academic staff competitiveness: 1) substantiation of 'personal competitiveness'; 2) substantiation of 'specialist competitiveness' in the context of different industries; 3) the substantiation of specifically academic staff competitiveness in the context of the specifics of higher education.

\section{References}

Baranova, S. (2012). Augstskolu docētāju profesionālā pilnveide tālākizglītībā (Higher Education Institution Teachers' Professional Development in Continuing Education). Doctoral dissertation. Riga: Latvijas Universitāte. (in Latvian).

Bogoyavlenskaya, D.B., \& Kliueva, O.A. (2013). To the Problem of Competitive Personality Concept. Procedia - Social and Behavioral Sciences. 80, 360-368. DOI: 10.1016/j.sbspro.2013.08.580.

Cummins, E. (2012). Senior European Experts Competitiveness in the European Union - Senior European Experts. Brussels. Retrieved December 8, 2019, from https://senioreuropeanexperts.org/paper/ competitiveness-european-union.

European Commission. (2019). Competitiveness. International Cooperation and Development. Brussels. Retrieved December 12, 2019, from https://ec.europa.eu/europeaid/sectors/economic-growth/privatesector-development/competitiveness_en.

Grebennikova, V.M., \& Rybkin, A.D. (2017). Analysis of the essential characteristics of the phenomenon of 'competitiveness'; in the aspect of preparing a contemporary teacher. Education and Pedagogical Sciences, 9 (2), 178-184. DOI: 10.17748/2075-9908-2017-9-5/2-178-183.

İriste, S. (2018). Prospective Managers'of Hospitality Business Competitiveness Evaluation and Development promotion in the Dual Study Environment of Higher Education Institution. Summary of the Doctoral Thesis. Jelgava: LLU.

Kalnina, I. (2010). Promotion and Evaluation of the Development of Secondary School Pupils' Competitiveness within the Environment of Non-Formal Commercial Education. Summary of the Doctoral Thesis. Jelgava: LLU.

Katans, E. (2019). Programmētāju profesionālās attīstības veicināšana mācīties spējīgā IT uzņēmumā zināšanu pārvaldības skatījumā (Promoting the Professional Development of Programmers in a Learning IT Company from the Perspective of Knowledge Management). Jelgava: LLU. (in Latvian).

Katane, I., Baltusite, R., \& Katans, E. (2017). Theoretical background for investigation and promotion of engineers competitiveness in education. In Proceedings of the $16^{\text {th }}$ International Scientific Conference 'Engineering for Rural Development', Vol. 16, Jelgava: LLU TF, 824-831.

Katane, I. (2010). Competitiveness of Personality as a New Concept in Modern Education and Pedagogy Science. In Proceedings of the $9^{\text {th }}$ International scientific Conference 'Engineering for Rural Development', May 27-28, 2010, Vol. 9, (pp. 327-334). Jelgava: LLU. 
Katane, I. (2011). Philosophic Methodological Bases for Evaluation of Educator's Competitiveness. In Proceedings of the $17^{\text {th }}$ Annual International Scientific Conference 'Science for Rural Development', May 18-20, 2011, Vol. 2, (pp. 218-224). Jelgava: LLU.

Katane, I., \& Īriste, S. (2013). Students' as Prospective Hospitality Specialists' Competitiveness in Theory and Practic. In Proceedings of the International Scientific Conference 'Society. Integration. Education', May 24-25, 2013, Vol. 1, (pp. 119-129). Rēzekne: RA.

Katane, I., \& Kalniņa, I. (2010). Skolēnu konkurētspējas attīstība neformālās komercizglītības vidē (Development of Pupils' Competitiveness in the Environment of Non-Formal Commercial Education). Jelgava: LLU. (in Latvian).

Maslow, A. (1968). Toward a psychology of being. $2^{\text {nd }}$ Edition. USA: Van Nostrand Reinhold Company Inc.

Lowden, K., Hall, St., Dr Elliot D., \& Lewin, J. (2011). Employers'perceptions of the employability skills of new graduates. London: University of Glasgow SCRE Centre and Edge Foundation.

Parker, G. (2008). Capitol Investments: Marketability of Political Skills. USA: University of Michigan Press.

Rothwell, A., \& Arnold, J. (2007). Self-perceived employability: Development and validation of a scale. Personnel Review, Vol. 36-1, (pp. 23-41).

Sarfraz, I., Rajendran, D., Hewege, C., \& Mohan, M.D. (2018). An exploration of global employability skills: A systematic research review. International Journal of Work Organisation and Emotion, Vol. 9-1, (pp. 63-88). Melbourne: Swinburne University of Technology.

Swanepoel, B., Erasmus, B., Van Wyk, M., \& Schenk, H.W. (2003). South African Human Resource Management: Theory \& Practice. Cape Town: Juta \& Co Ltd.

Teichler, U. (2007). Studium und Berufschancen: Was macht den Unterschied aus (Studies and career opportunities: what makes the difference). Beiträge zur Hochschulforschung, 29(4), 10-31. (in German).

Unger, M., Zaussinger, S., Thaler, B., Dibiasi, A., Grabher, A., Terzieva, B., Litofcenko, J., Binder, D., Brenner, J., Stjepanovic, S., Mathä, P., \& Kulhanek, A. (2010). Bericht zur sozialen Lage der Studierenden: Studierenden - Sozialerhebung 2009 (Report on the Social Situation of Students: Students - Social Survey 2009). Wien: Institut für Höhere Studien (IHS). (in German).

Андреев, В.И. (2004). Учебный курс для творческого саморазвития конкурентоспособности (Training Course for Creative Self-development of Competitiveness). Казань: Центр инновационных технологий. (in Russian).

Андреев, В.И. (2013). Конкурентология (Competitiveness Science). Казань: Центр инновационных технологий. (in Russian).

Донина, И.А., \& Стырова, Е.А. (2018). Конкурентоспособность педагога как тенденция развития современного образования (The competitiveness of the teacher as a trend in the development of modern education). Санкт - Петербургский Образовательный Вестник, 29-34. (in Russian).

Митина, Л.М. (2003). Психология развития конкурентоспособной личности (Developmental Psychology of the Competitive Personality). Москва: МПСИ (in Russian).

Плугина, М.И. (2016). Детерминанты профессионального становления преподавателя высшей школы в современных социокультурных условиях (Determinants of Professional Formation of Teachers in Contemporary Social Cultural Environment of Higher Education). Вестник РУДН, Педагогика и психология, 96-104. (in Russian).

Скляр, Е.С. (2018). Конкурентоспособность преподавателя ВУЗа как одно из условий повышения качества образовательных услуг (Competitiveness of a university teacher as one of the conditions for improving the quality of educational services). Иннов: электронный научный журнал. Retrieved December 11, 2019, from https://www.innov.ru/science/economy/konkurentosposobnost-prepodavatelya/ ?fbclid=IwAR2pzB5AlUCe_F37V0eo7hzOREc6TSADVa-VrEouf-83-nG_tid8hdJ0e2E. (in Russian).

Сохач, А.Я., \& Плугина, М.И. (2015). Конкурентоспособный преподователь - конкурентоспособный выпускник ВУЗа (A competitive teacher - a competitive graduate of university). Науки об образовании. Retrieved December 13, 2019, from https://cyberleninka.ru/article/n/konkurentosposobnyy-prepodavatelkonkurentosposobnyy-vypusknik-vuza/viewer. (in Russian).

Суязова, Л.В., Мустафина, Д.А., Ребро, И.В., \& Рахманкулова, Г.А. (2013). Структура конкурентоспособности будущего инженера в машиностроении (The Structure of Competitiveness of an Intended Engineer in Mechanical Engineering). Международный студенческий научный вестник. Retrieved November 30, 2019, from https://www.eduherald.ru/ru/article/view?id=70 (in Russian).

Харченко, Л.Н. (2014). Проектирование программы подготовки преподавателя высшей школы (Projecting Programmes to Prepare Teachers in Higher Education Institutions). Москва: Литагент Директмедиа. (in Russian). 
Холодцева, Е.Л. (2006). Конкурентоспособность в системе разноуровневых характеристик личности специалистов социальной сферы (Competitiveness in the system of multilevel personality characteristics of specialists in the social sphere). Диссертация. Барнаул: БГПУ. (in Russian).

Чупрова, О.Ф. (2004). Формирование конкурентоспособности личности будущего учителя в про-цессе экспертно-аналитической деятельности (Formation of the Competitiveness of the Personality of the Prospective Teacher in the Process of Expert-Analytical Activity). Диссертация. Иркутск: Иркутский Государственный университет. (in Russian).

Шаповалов, В.И.(2005). Конкурентоспособностьличности в парадигме инновационного педагогического менеджмента (Personality competitiveness in the paradigm of innovative educational management). Ярославский Педагогический Вестник. Retrieved December 13, 2019, from https:/cyberleninka. ru/article/n/konkurentosposobnost-lichnosti-v-paradigme-innovatsionnogo-pedagogicheskogomenedzhmenta/viewer. (in Russian).

Широбоков, С. (2000). Оценка качества подготовки конкурентоспособного специалиста 6 педагогическом вузе (Assessment of the quality of training a competitive specialist in a pedagogical university). Диссертация. Омск: Отслый государственный университет. (in Russian). 